\title{
UNIVERSITY SOCIAL RESPONSIBILITY - GOOD PRACTICES OF POLISH HIGHER EDUCATION INSTITUTIONS
}

\author{
K. Szelagowska-Rudzka \\ Gdynia Maritime University \\ 81-87 Morska str., Gdynia, 81-225, Poland; \\ k.szelagowska-rudzka@wpit.umg.edu.pl
}

\begin{abstract}
All organizations, including Higher Education Institutions (HEIs), should be socially responsible. Therefore, the article aims to answer the following research questions: How are the principles of social responsibility implemented by Polish HEIs? Through what good practices are they manifested? What formal national regulations support these activities? To answer those questions, the principles of the Declaration of University Social Responsibility and of good practices implemented by 23 universities, the first signatories of this Declaration, were reviewed. The applied research method has incorporated the analysis of the literature on the subject, documents and websites of the above 23 universities. The study presents the essence of university social responsibility and the special role of universities in promoting and implementing the principles of sustainable development and social responsibility. The activities of the Polish public administration in partnership with the representatives of HEIs, businesses, NGOs which led to the creation of the Declaration of USR were outlined. Examples of good practices applied by the examined universities and the ensuing conclusions were briefly discussed.

Keywords: university social responsibility, higher education institutions, principles for responsible management education, declaration of university social responsibility

For citation: Szelągowska-Rudzka K. University Social Responsibility-Good Practices of Polish Higher Education Institutions. University Management: Practice and Analysis. 2019; 23(5): 43-52. DOI: 10.15826/umpa.2019.05.040
\end{abstract}

\section{Introduction}

All organizations (not just businesses) [1-3], including HEIs [4-5] should be socially responsible, and hence oriented to building relations with their stakeholders. HEIs are supposed to play a special social and civilizational role [6-8]. In their activities, they simultaneously focus on research, education and serving the society (building relations with stakeholders). Thus, they can promote sustainable development based on principles of social responsibility [9] not only in education, but also in management and operation. HEIs are increasingly involved in these activities [10-11], as is confirmed by reports of various international organizations [8]. For example, the world's best universities, such as the University of Cambridge, California Institute of Technology, Stanford University, Massachusetts Institute of Technology, Harvard University and Princeton University, implement sustainable development (SD) strategies based on the 2015 United Nations 17 Sustainable Development Goals (SDGs ${ }^{1}$ ) [13]. Principles for

\footnotetext{
${ }^{1}$ These principles involve a multi-dimensional approach to SD. They were included in the Agenda for Sustainable Development 2030 and adopted for use in 2015 by UN Member States, including the EU
}

Responsible Management Education (PRME) is another external initiative document supporting the activity of HEIs [14]. This platform popularizes issues of SD in university business programs around the world based on six principles of responsible managerial education developed in 2007 under the UN Global Compact program. These principles are as follows: purpose, values, method, research, partnership and dialogue [15]. PRME enables students to understand the issues of SD during their studies, so that in the future-as participants in economic life - they could balance its goals with the economic goals of businesses [16].

This article aims to answer the following research questions:

- How are the principles of social responsibility implemented by Polish HEIs;

- Through what good practices are they manifested?

-What formal national regulations support these practices?

countries. These principles include: eradication of extreme poverty and hunger, activity for climate and environmental protection, ensuring responsible consumption and production, and the quality of life and peaceful coexistence based on partnership and sustainable patterns [12]. 
To answer those questions, the principles of the Declaration of University Social Responsibility (USR) and of good practices implemented by 23 universities, the first signatories of this Declaration, were reviewed. The applied research method has incorporated the analysis of the literature on the subject, documents and websites of the above 23 universities.

The study also presents the definition and the essence of USR, and it introduces the special role of universities in promoting and implementing the principles of SD and SR. The activities of the Polish public administration in partnership with the representatives of HEIs, businesses, NGOs which led to the creation of the Declaration of University Social Responsibility were outlined. Examples of good practices applied by the examined universities, the first signatories of the Declaration, were briefly discussed. Based on these practices, benefits and conclusions for the future regarding the implementation of SR in Polish universities were identified.

\section{Definition and Essence of University Social Responsibility}

The idea of social responsibility is most often called Corporate Social Responsibility (CSR) and is associated with enterprises. Already P. Drucker stated that it is a relationship between subjects and the broadly understood society, a relationship for which these entities are responsible [17]. The European Commission is of a similar opinion [8]. CSR can be defined as responsible and ethical performance of economic, social, and environmental aspects that can improve the quality of life for different stakeholders, such as employees, suppliers, consumers, government, community, society, etc. Organizations that promote social and environmental initiatives have the power to evoke positive reactions between stakeholders [4]. SR is defined by Norm ISO 26000 as the «responsibility of an organization for the impacts of its decisions and activities on society and the environment, through transparent and ethical organization that: contributes to sustainable development, including health and the welfare of society; takes into account the expectations of stakeholders; is in compliance with applicable law and consistent with international norms of behavior; is integrated through the organization and practiced in its relationships» [18].

A socially responsible university is a higher education institution whose responsibility towards society concerns preparing graduates to act as knowledge workers and building close relations with the economic practice and local governments [19]. Universities are organizations that create and transfer knowledge and competencies; therefore, being socially responsible, they should take into account their stakeholders' expectations by shaping economic, social and ethical relations with them; operate within the legal framework for higher education; strive to build organizational culture conducive to social innovation and to be a center of transmission and transformation of culture, good practices and civic attitudes [20,7].

USR primarily means ensuring the appropriate quality of education, transfer of knowledge to the economy to stimulate its growth, education of future elites of society, active social policy towards students and employees, and elimination of social barriers [8]. It should be based on managing the university according to the code of good practices and on shaping socially desirable attitudes among stakeholders, especially students [21].

Therefore, USR is the ability to develop and promote a group of principles and values through responsible management, teaching, research, and community involvement (building relations with stakeholders). These four key areas do not work in isolation but as a whole [22].

\section{Activities of Polish HEls and the Declaration of University Social Responsibility}

Issues of social responsibility at HEIs in Poland are promoted, among others, by offering a subject related to CSR in study programs and by postgraduate studies in this field. Today, HEIs offering postgraduate studies in CSR include: Kozminski University, University of Ecology and Management (Warsaw), Management School of Silesian University (Chorzow), University of Opole, Wroclaw University of Economics, Gdansk University of Technology, Collegium Da Vinci (Poznan), University of Economics in Katowice, Poznan University of Economics, Warsaw University of Life Sciences (SGGW) [23-24].

The development of USR and shaping higher education goals in Poland according to the principles of sustainable development is also based on the PRME platform (universities of economics) and the Declaration of University Social Responsibility.

Among business schools in Poland only five decided to join the PRME initiative. These are Warsaw School of Economics, Poznan University of Economics, Kozminski University, Poznan University College of Business, and the Faculty of Management at University of Warsaw (only the first two-both are 
public schools - have submitted the required Sharing Information on Progress Report) [23].

The Declaration is a result of grassroots activity of representatives of academic institutions and government administration supporting such initiatives. In 2009, the Sustainable Development and Corporate Social Responsibility Team was established at the then Ministry of Development. The team created a platform for dialogue, exchange of experience and good practices between public administration, business, trade unions, industry and sector associations, research and academic community as well as non-governmental organizations in the field of sustainable development and CSR [25]. The team is advised by a working group on USR. The Declaration is the result of the group's work and a tool through which it accomplishes its tasks. The declaration was signed on November 16, 2017 by 23 HEIs: Kozminski University, University of Bielsko-Biala, the Center of Postgraduate Medical Education, the Witelon State University of Applied Sciences in Legnica, Gdansk University of Technology, Lodz University of Technology, Wroclaw University of Science and Technology, Powiślańska School in Kwidzyn, SGH Warsaw School of Economics, Vistula School of Hospitality, Medical University of Silesia in Katowice, University of Gdansk, Krakow University of Economics and Business, Poznan University of Economics and Business, Wroclaw University of Economics and Business, University of Silesia in Katowice, Adam Mickiewicz University in Poznan, University of Lodz, University of Agriculture in Krakow, University of Wrocław, WSB University, Humanitas University in Sosnowiec, Warsaw Management University.

The Declaration is based on the SDGs and explains how a socially responsible university can contribute to their achievement [24]. The Declaration is a voluntary commitment of HEIs to promote the idea of SD and SR in educational activities, scientific research, and management and organizational solutions at university in accordance with the twelve principles contained therein. Its purpose is to build broad social awareness of the role of universities in shaping conditions for the countries' sustainable socio-economic development. The Declaration is addressed to all public and private universities.

The Declaration [26] reads: «The special role of universities as places that create and transfer knowledge about the surrounding reality obliges them to include and apply the principles of SR in all areas of activity and to promote these principles among stakeholders. Bearing in mind the good of higher education in Poland, being aware of our role in implementing the principles of sustainable development, ensuring high quality research and education, and ensuring comprehensive development of the academic community, we commit ourselves» to comply with the twelve principles contained in the declaration (Tab. 1). These principles deal with various aspects of the university operation, including teaching and research, dialogue with stakeholders and internal organization. A university joining the initiative pledges to develop a selected area (or several ones) from among the listed in a spirit of social responsibility.

The growing popularity of the USR Declaration in Poland is evidenced by the fact that another sixty HEIs joined it in $2019^{2}$, both public and private ones [27].

\section{Analysis of good practices at selected Polish HEls Research methodology}

The study analyzed documents and websites of the universities - the first signatories to the SRU Declaration from 2017. Table 1 presents only examples of good practices implemented by those universities that are part of an individual principle of the

${ }^{2}$ Among others, these are the leading Polish universities, such as: AGH University of Science and Technology in Krakow, Medical University of Gdańsk, Warsaw University of Technology, University of Economics in Katowice, Nicolaus Copernicus University in Toruń, Silesian University of Technology, Cracow University of Technology, but also other public and private universities of different profiles, e. $g$. the Feliks Nowowiejski Academy of Music in Bydgoszcz, Academy of Fine Arts in Gdańsk, the University School of Physical Education in Wrocław, Polish-Japanese Academy of Information Technology, Cardinal Wyszyński University in Warsaw, Medical University of Lodz, WSB University in Gdansk [27].

Table 1

\section{Examples of good practices of selected HEIs in Poland implemented on the basis of the principles of the Declaration of USR}

\begin{tabular}{|l|l|l|}
\hline Name of the university & Name of the practice & \multicolumn{1}{|c|}{ A brief description of the practice } \\
\hline $\begin{array}{l}\text { Principle 1. Cultivate academic values prescribed, among others, in the "Code of Researcher's Ethics», in particular: diligence, } \\
\text { objectivity, independence, openness and transparency }\end{array}$ \\
\begin{tabular}{l|l|l|l} 
SGH & Code of Ethics \\
Warsaw School of & Representatives of various groups of SGH employees were involved in the partici- \\
Economics & Warsaw School of \\
Economics
\end{tabular} & $\begin{array}{l}\text { patory development of the Code. It was adopted by the SGH Senate in December } \\
\text { SGH Ethics Handbook. It contains examples of ways of conduct and good prac- } \\
\text { tices; it may be supplemented by employees. }\end{array}$ \\
\hline
\end{tabular}




\begin{tabular}{|c|c|c|}
\hline Name of the university & Name of the practice & A brief description of the practice \\
\hline $\begin{array}{l}\text { University of Silesia } \\
\text { in Katowice }\end{array}$ & $\begin{array}{l}\text { Silesian Science } \\
\text { Festival (SSF) }\end{array}$ & $\begin{array}{l}\text { During the SSF, scientists share their knowledge, innovative research results, } \\
\text { their application in industry and economy; they present inventions and the latest } \\
\text { achievements to the public through workshops, lectures and shows adapted to dif- } \\
\text { ferent age groups. }\end{array}$ \\
\hline \multicolumn{3}{|c|}{$\begin{array}{l}\text { Principle 2. Shape social and civic attitudes of future elites conducive to building community, creativity, openness and communi- } \\
\text { cation, as well as social sensitivity and work culture }\end{array}$} \\
\hline $\begin{array}{l}\text { University of } \\
\text { Bielsko-Biała }\end{array}$ & Sandals for Gambia & $\begin{array}{l}\text { The goal of the Science Club 'Horizon' initiative is to collect and transport sandals } \\
\text { for poor children in Gambia. In 2018, the campaign brought together over } 320 \text { rep- } \\
\text { resentatives of education, culture, media, and administration. Over } 22,000 \text { sandals } \\
\text { went to children in Gambia. }\end{array}$ \\
\hline $\begin{array}{l}\text { Humanitas Univer- } \\
\text { sity } \\
\text { in Sosnowiec }\end{array}$ & $\begin{array}{l}\text { Development of } \\
\text { lifelong education }\end{array}$ & $\begin{array}{l}\text { The University of the Third Age thrives at the university, and various projects to } \\
\text { activate senior citizens are implemented, e. g. «the Sosnowiec Academy of Citizens' } \\
\text { Activity». In various cities of the region, Children's Universities of the Humanitas } \\
\text { University are set up to show the youngest (6-12-year-olds) the diversity of the } \\
\text { world of science. There is also Youth University popularizing knowledge in the } \\
\text { fields of engineering, marketing, management, PR, chemistry, physics, biology, } \\
\text { mnemonics and psychology among teenagers (13-17-year-olds). }\end{array}$ \\
\hline $\begin{array}{l}\text { Medical University } \\
\text { of Silesia in Kato- } \\
\text { wice }\end{array}$ & $\begin{array}{l}\text { Culinary and edu- } \\
\text { cational workshops } \\
\text { «Colorful means } \\
\text { healthy» }\end{array}$ & $\begin{array}{l}\text { This is an initiative of Medical University of Silesia in Katowice (Operational } \\
\text { Program Knowledge Education Development), in partnership with the municipality } \\
\text { of Siemianowice Sląskie. The aim of educational, sensory, culinary workshops in } \\
\text { molecular cuisine is to shape or change children's attitudes, beliefs, opinions and } \\
\text { practical skills. }\end{array}$ \\
\hline $\begin{array}{l}\text { Wroclaw University } \\
\text { of Economics and } \\
\text { Business }\end{array}$ & $\begin{array}{l}\text { Green Days } 2019 \\
\text { Wroclaw University } \\
\text { of Economics and } \\
\text { Business (WUEB) } \\
\text { for the Planet and Fu- } \\
\text { ture Generations }\end{array}$ & $\begin{array}{l}\text { On the occasion of the Earth Day, the Green Team, together with the ENAC- } \\
\text { TUS scientific club, organized two days' (16-17 April 2019) activities devoted } \\
\text { to the issues of university responsibility towards the planet and future genera- } \\
\text { tions. The program included: workshops, lectures, discussion with representa- } \\
\text { tives of the university administration about the desired «green» and pro-social } \\
\text { initiatives at WUEB }\end{array}$ \\
\hline $\begin{array}{l}\text { Adam Mickiewicz } \\
\text { University in Poznan }\end{array}$ & Academic Days & $\begin{array}{l}\text { The main goal of the Academic Days is to popularize knowledge in the field of } \\
\text { natural sciences among secondary school students by participating in lectures and } \\
\text { in labs, workshops and seminars conducted by the employees of the Faculty of } \\
\text { Biology. Students acquire knowledge, skills and social competences in the field of } \\
\text { research of the world of nature and biology }\end{array}$ \\
\hline $\begin{array}{l}\text { Warsaw Manage- } \\
\text { ment Universi- } \\
\text { ty (WMU) }\end{array}$ & $\begin{array}{l}\text { Academy of Mana- } \\
\text { gerial Competence }\end{array}$ & $\begin{array}{l}\text { The key task of the project is to organize free cyclical trainings in responsible } \\
\text { management for students and graduates of WMU and for the local community. } \\
\text { The trainings are conducted by the top managerial staff of renowned national and } \\
\text { international companies. }\end{array}$ \\
\hline $\begin{array}{l}\text { University of } \\
\text { Wrocław (UWr) }\end{array}$ & $\begin{array}{l}\text { Popularization of } \\
\text { science }\end{array}$ & $\begin{array}{l}\text { UWr is open to children, youth, and their parents. Faculties prepare lectures on } \\
\text { natural and life sciences, STEM, law, social, and philosophical disciplines and } \\
\text { humanities. Studium Generale aims to build bridges between specialist field areas } \\
\text { in order to allow people to know and understand better the world around us. The } \\
\text { University participates in The Lower Silesian Festival of Science. During lectures, } \\
\text { workshops, laboratory, classes, researchers present the achievements of science in } \\
\text { layman's terms. }\end{array}$ \\
\hline
\end{tabular}

Principle 3. Disseminate the ideas of equality, diversity, tolerance and respect, and protect human rights in relation to the entire academic community and its environment

\begin{tabular}{|l|l|l|}
\hline WSB University & $\begin{array}{l}\text { Managing the } \\
\text { diversity }\end{array}$ & $\begin{array}{l}\text { About } 1,000 \text { students from } 65 \text { countries study at WSB University. Supporting } \\
\text { diversity through respect for the values, traditions, norms, customs and culture } \\
\text { of various countries has made WSB University unique in the region. During } \\
\text { matriculation, foreign students appear in national costumes; they speak about } \\
\text { traditions, culture and cuisine of their countries during specially organized days, } \\
\text { exchange their experience by participating in educational and research projects } \\
\text { at the university. }\end{array}$ \\
\hline
\end{tabular}




\begin{tabular}{|c|c|c|}
\hline Name of the university & Name of the practice & A brief description of the practice \\
\hline $\begin{array}{l}\text { Medical University } \\
\text { of Silesia in Kato- } \\
\text { wice }\end{array}$ & $\begin{array}{l}\text { The project «From } \\
\text { kindergarten to sen- } \\
\text { ior» co-sponsored by } \\
\text { the City of Katowice }\end{array}$ & $\begin{array}{l}\text { Every year, MUSK organizes several free forms of sports (e. g. Nordic walking) } \\
\text { and educational activities (workshops, lectures) for the residents of Katowice. The } \\
\text { project assumes that health prophylaxis will definitely be more effective if its } \\
\text { program reaches entire social structures, from the youngest to the seniors of the } \\
\text { City of Katowice. }\end{array}$ \\
\hline $\begin{array}{l}\text { University of Gda- } \\
\text { nsk (UG) }\end{array}$ & $\begin{array}{l}\text { Immigrant student } \\
\text { at school and in the } \\
\text { environment-im- } \\
\text { proving intercultural } \\
\text { competences }\end{array}$ & $\begin{array}{l}\text { In May 2015, the President of Gdańsk inaugurated the work of the first Polish } \\
\text { cross-sectoral and interdisciplinary team for the model of integration of immi- } \\
\text { grants. Its task was to create an inventory of resources and opportunities to support } \\
\text { immigrants in Gdansk, and to identify their most important needs and problems. } \\
\text { The Faculty of Social Sciences of the UG participated in the team's activities } \\
\text { and developed a program and methods of training for teachers. Its purpose is to } \\
\text { develop the knowledge and competences of educators and psychologists in the field } \\
\text { of education and support of the development and integration of immigrant students } \\
\text { at Polish schools. }\end{array}$ \\
\hline \multicolumn{3}{|c|}{ Principle 4. Expand curricula to include issues of ethics and CSR, sustainable development and social innovation } \\
\hline $\begin{array}{l}\text { Kozminski Univer- } \\
\text { sity }\end{array}$ & $\begin{array}{l}\text { CSR. Goals of } \\
\text { Sustainable Develop- } \\
\text { ment in the Compa- } \\
\text { ny's Strategy-post- } \\
\text { graduate studies }\end{array}$ & $\begin{array}{l}\text { Postgraduate studies are specialized and are conducted in partnership with De- } \\
\text { loitte. The curriculum aims to supplement knowledge about shaping ethical and } \\
\text { responsible business strategies using the SDGs of the UN, as well as to equip the } \\
\text { participants with skills and competences highly valued on the market for the effec- } \\
\text { tive use of various instruments of CSR in a modern organization. }\end{array}$ \\
\hline $\begin{array}{l}\text { SGH Warsaw School } \\
\text { of Economics }\end{array}$ & $\begin{array}{l}\text { Compulsory e- } \\
\text { learning subject } \\
\text { «Corporate Social } \\
\text { Responsibility» }\end{array}$ & $\begin{array}{l}\text { The subject developed as part of extending the SGH curriculum with issues of } \\
\text { ethics and SR. Each module contains a theoretical introduction, a case study and } \\
\text { opinions of practitioners from organizations who are leaders in a given topic. }\end{array}$ \\
\hline \multicolumn{3}{|c|}{$\begin{array}{l}\text { Principle 5. Run projects implementing the principles of } S R \text {, in particular regarding the management of diversity in the work- } \\
\text { place, employee volunteering, promotion of ethics, cross-sectoral cooperation, and socially engaged marketing }\end{array}$} \\
\hline $\begin{array}{l}\text { Poznan University } \\
\text { of Economics and } \\
\text { Business }\end{array}$ & $\begin{array}{l}\text { Volunteer WorkDay } \\
\text { at UEP }\end{array}$ & $\begin{array}{l}\text { The idea of the initiative is to introduce the notion of employee volunteer work and } \\
\text { to present voluntary activities conducted by business and NGOs and by employees } \\
\text { and students of PUEB }\end{array}$ \\
\hline University of Gdansk & $\begin{array}{l}\text { Academy of Anima- } \\
\text { tor-the Promoter of } \\
\text { Science }\end{array}$ & $\begin{array}{l}\text { The project implemented by the Faculty of Chemistry consisted of strengthening } \\
\text { the dialogue between science and society in the field of experimental sciences, } \\
\text { transferring knowledge based on scientific evidence and activity of employee } \\
\text { volunteer work. It was associated with the Baltic Festival of Science. }\end{array}$ \\
\hline \multicolumn{3}{|c|}{$\begin{array}{l}\text { Principle 6. Undertake scientific research and implementation activities which, in partnership with other academic centers from } \\
\text { around the world, the enterprise sector, public administration and NGOs, can contribute to solving important social problems }\end{array}$} \\
\hline WSB University & $\begin{array}{l}\text { Building long-term } \\
\text { relations with the } \\
\text { economic environ- } \\
\text { ment }\end{array}$ & $\begin{array}{l}\text { WSB University develops effective coope-ration and partnership relations with } \\
\text { enti-ties of the social and economic environ-ment, among others, through the } \\
\text { Experts' Council of WSB University. As one of the first in Poland, it introduced a } \\
\text { dual educa-tion model ensuring graduates' better pre-paration to the needs of the } \\
\text { labor market. }\end{array}$ \\
\hline $\begin{array}{l}\text { Gdansk University of } \\
\text { Technology }\end{array}$ & $\begin{array}{l}\text { Knowledge Bridge- } \\
\text { a portal with knowl- } \\
\text { edge for you }\end{array}$ & $\begin{array}{l}\text { Bridge of Knowledge is a platform that aims to connect creative scientists with } \\
\text { innovative businessmen. Bridge gathers science offers for commercial partnerships } \\
\text { This platform is filled with opportunities which give access to innovative scientists, } \\
\text { their projects, laboratories and more. It provides new ways to bring business to the } \\
\text { next level. }\end{array}$ \\
\hline \multicolumn{3}{|c|}{$\begin{array}{l}\text { Principle 7. Develop inter-university, national and international cooperation to enable adaptation and strengthening of the best } \\
\text { practices in the field of CSR }\end{array}$} \\
\hline $\begin{array}{l}\text { Poznan University } \\
\text { of Economics and } \\
\text { Business }\end{array}$ & $\begin{array}{l}\text { Conference «Prob- } \\
\text { lems of CSR in } \\
\text { didactics and scien- } \\
\text { tific research. PRME } \\
\text { Prospects» } 3-4 \text { April } \\
2017\end{array}$ & $\begin{array}{l}\text { The conference aimed to discuss the importance of CSR in the modern world. } \\
\text { Universities' obligation to prepare students - future employees - to perform profes- } \\
\text { sional roles responsibly was discussed, the results of CSR research were presented, } \\
\text { and contemporary interpretations of this idea and directions of its development } \\
\text { were considered. }\end{array}$ \\
\hline
\end{tabular}




\begin{tabular}{|c|c|c|}
\hline Name of the university & Name of the practice & A brief description of the practice \\
\hline $\begin{array}{l}\text { University of Silesia } \\
\text { in Katowice }\end{array}$ & $\begin{array}{l}\text { 14th Youth Climate } \\
\text { Summit before } \\
\text { COP24, Conference } \\
\text { of Youth (COY) }\end{array}$ & $\begin{array}{l}\text { This project preceded the climate summit in Katowice (December } 2-14,2018) \text { Dur- } \\
\text { ing the meeting, issues of the climate policy in the regional and global dimensions } \\
\text { as well as environmental changes were raised. The program included thematic } \\
\text { workshops, sessions and panels. }\end{array}$ \\
\hline \multicolumn{3}{|c|}{$\begin{array}{l}\text { Principle 8. Ensure the organizational order at university, building university management on the foundation of SR, both in } \\
\text { strategic documents and the resulting activities in order to comprehensively develop the academic community and to effectively } \\
\text { implement the university mission. }\end{array}$} \\
\hline $\begin{array}{l}\text { Lodz University } \\
\text { of Technology (LUT) }\end{array}$ & $\begin{array}{l}\text { IDEA BOX-scien- } \\
\text { tists and students' } \\
\text { ideas for the develop- } \\
\text { ment of the LUT }\end{array}$ & $\begin{array}{l}\text { This is a regular activity implemented under the LUT task budget aimed at improv- } \\
\text { ing conditions of work and study. Employees and students can submit their ideas } \\
\text { how to develop the university via a special website. The projects to be implement- } \\
\text { ed are selected by the university authorities after consultation with the academic } \\
\text { community. }\end{array}$ \\
\hline $\begin{array}{l}\text { SGH Warsaw School } \\
\text { of Economics }\end{array}$ & $\begin{array}{l}\text { Employee budget at } \\
\text { the SGH }\end{array}$ & $\begin{array}{l}\text { The employee budget is a separate amount of financial resources whose allocation } \\
\text { is co-decided by employees. A project can be submitted individually or together } \\
\text { with other employees. Ideas for implementation are selected by universal voting } \\
\text { via the Internet. Ideas cover improving the university infrastructure, improving } \\
\text { social conditions and other initiatives supporting professional development, health } \\
\text { or increasing the comfort of work. }\end{array}$ \\
\hline $\begin{array}{l}\text { Gdansk University of } \\
\text { Technology (GUT) }\end{array}$ & $\begin{array}{l}\text { Citizens' Budg- } \\
\text { et (CB) }\end{array}$ & $\begin{array}{l}\text { CB is part of the GUT budget allocated in a given calendar year from the reserve } \\
\text { available to the rector. Its purpose may be decided by employees, students and doc- } \\
\text { toral students of the GUT in an open online competition. CB relates to investment } \\
\text { and renovation projects that fall within the competence of the university authorities. }\end{array}$ \\
\hline \multicolumn{3}{|c|}{$\begin{array}{l}\text { Principle 9. Ensure transparency of the university's activities, among others, by evaluating the results, promoting and dissemi- } \\
\text { nating the output, and identifying the person or team coordinating these activities }\end{array}$} \\
\hline $\begin{array}{l}\text { Lodz University of } \\
\text { Technology }\end{array}$ & $\begin{array}{l}\text { Promoting and dis- } \\
\text { seminating research } \\
\text { results via the Inter- } \\
\text { net and through the } \\
\text { YouTube Channel }\end{array}$ & $\begin{array}{l}\text { The activity aims to popularize science in society by presenting scientific issues in } \\
\text { an attractive form, via the Internet and You Tube, and in a way understandable to } \\
\text { a wide audience. The cycle is mainly addressed to secondary school students and } \\
\text { people interested in scientific explanation of everyday life phenomena. }\end{array}$ \\
\hline University of Gdansk & $\begin{array}{l}\text { Implementation of } \\
\text { the Open Access } \\
\text { Policy (OAP) at the } \\
\text { University of Gdańsk }\end{array}$ & $\begin{array}{l}\text { The strategic goal of the project is to increase the number of publications of UG } \\
\text { employees and doctoral students made available on the basis of free licenses and } \\
\text { indexed in research databases as Open Access documents. The activities, initi- } \\
\text { ated in 2017, include: creation of internal legal acts and procedures regulating the } \\
\text { issues of depositing and sharing scientific work; preparation of technical facilities; } \\
\text { support of faculty research journals (applications to the Ministry of Science and } \\
\text { Higher Education) }\end{array}$ \\
\hline
\end{tabular}

Principle 10. Minimize the negative impact of the activities of the academic community and its stakeholders on the natural environment in all its dimensions

\begin{tabular}{|l|l|l|}
\hline $\begin{array}{l}\text { Wroclaw University } \\
\text { of Science and Tech- } \\
\text { nology (WUST) }\end{array}$ & $\begin{array}{l}\text { Monitoring the air } \\
\text { quality at the WUST } \\
\text { campus }\end{array}$ & $\begin{array}{l}\text { The initiative is implemented by employees and students under the project entitled } \\
\text { «The Use of Innovative Sensor Systems to Assess Air Quality at the Wrocław } \\
\text { University of Technology Campus.» The impact of the type of building develop- } \\
\text { ment, transport and the green areas in shaping air quality in this part of Wrocław is } \\
\text { studied. Measurements are made in selected parts of the campus, at short intervals, } \\
\text { and their results are updated on the project website every } 15 \text { minutes. }\end{array}$ \\
\hline $\begin{array}{l}\text { University of } \\
\text { Wrocław }\end{array}$ & $\begin{array}{l}\text { Climate and environ- } \\
\text { mental emergency }\end{array}$ & $\begin{array}{l}\text { The Council of the Faculty of Biological UWr asked the University authorities to } \\
\text { immediately proclaim «a climatic and environmental state of emergency» at the } \\
\text { University and to set up an interdisciplinary team of scientists who would engage } \\
\text { in a social dialogue, audit the environmental costs of the University's operation, } \\
\text { and prepare substantive grounds to involve the university in a public debate on the } \\
\text { climate and ecological crisis. }\end{array}$ \\
\hline
\end{tabular}




\begin{tabular}{|l|l|l|}
\hline \begin{tabular}{l} 
Name of the university \\
\hline $\begin{array}{l}\text { Principle 11 Conduct a dialogue with stakeholders on the priorities of the university social responsibility policy and inform } \\
\text { about its results }\end{array}$
\end{tabular} \\
\hline WSB University & $\begin{array}{l}\text { Involvement in the } \\
\text { local development }\end{array}$ & $\begin{array}{l}\text { Being aware of the importance of regional identity and local development, WSB } \\
\text { University actively cooperates with local government, associations, and cultural } \\
\text { and educational organizations. WSB University employees participate in develop- } \\
\text { ing the voivodship development strategy, cities' development strategies, revitaliza- } \\
\text { tion policies and urban policies; they prepare expert opinions on behalf of public } \\
\text { administration bodies. }\end{array}$ \\
\hline $\begin{array}{l}\text { Poznan University } \\
\text { of Economics and } \\
\text { Business }\end{array}$ & $\begin{array}{l}\text { Gala of the «Ace of } \\
\text { Responsible Busi- } \\
\text { ness 2018» poll }\end{array}$ & $\begin{array}{l}\text { The goal of the poll was to select and promote socially responsible practices used } \\
\text { by large and smaller Greater Poland companies operating only locally. The awards } \\
\text { were granted in the categories: fair market practices, labor relations, environmental } \\
\text { protection and social involvement. }\end{array}$ \\
\hline
\end{tabular}

Principle 12 Be guided by the principles of ethics and responsibility in the process of teaching and conducting scientific research to ensure optimal conditions for stakeholders to use knowledge, intellectual capital and university achievements

\begin{tabular}{l|l|l}
$\begin{array}{l}\text { Kozminski Univer- } \\
\text { sity (KU) }\end{array}$ & $\begin{array}{l}\text { Survey among } \\
\text { academic teachers } \\
\text { related to the HR Ex- } \\
\text { cellence in Research } \\
\text { Award* }\end{array}$ & $\begin{array}{l}\text { In 2016, KU conducted a survey among academic teachers related to applying } \\
\text { for the HR Excellence in Research Award and developed a strategy for Human } \\
\text { Resources Management for KU teachers in accordance with the European Charter } \\
\text { for Researchers and the Code of Conduct in recruiting researchers. }\end{array}$ \\
\hline
\end{tabular}

Other universities that have the HR Excellence in Research Award and HRM strategy and conducted research among their own academic staff are: SGH Warsaw School of Economics, Adam Mickiewicz University in Poznan, Nicolaus Copernicus University in Toruń, Medical University of Lodz, University of Gdansk, Lodz University of Technology, Gdansk University of Technology, Medical University of Silesia in Katowice, Poznan University of Economics and Business, University of Lodz, University of Silesia in Katowice, Vistula University, Wroclaw University of Science and Technology, Wroclaw University of Economics and Business

Source: own study based on: [24,28-34]

* The distinction of HR Excellence in Research is awarded by the European Commission to the institutions that implement The Human Resources Strategy for Researchers - HRS4R, observing the rules and guidelines contained in the European Charter for Researchers and the Code of Conduct for the Recruitment of Researchers (https://euraxess.ec.europa.eu/jobs/hrs 4 r).

Declaration. Due to the limited volume of the article, an exhaustive review of all activities undertaken by the studied universities cannot be conducted.

\section{Conclusion}

Research goals were achieved through the conducted analysis. It was found that Polish HEIs voluntarily and increasingly more often implement the principles of SR mainly based on the Declaration of USR, less often applying the PRME principles. For HEIs, the Declaration is the basic set of formal national regulations regarding the USR. It is based on the principles of SDGs, adapting them to the specificity of higher education institutions and invoking some of these principles in particular points.

In particular, it refers to principle 4 (quality education) aiming to ensure inclusive, equitable quality education, including education on sustainable development and promoting lifelong learning opportunities for all. It refers to principles aiming to strengthen and develop scientific research supporting technological advances, developing innovation and entrepreneurship (principle 9), to principles promoting inclusive and sustainable economic growth, full and productive employment and decent work (principle 8), to principles counteracting all forms of discrimination in different types of organizations (principle 5), to principles conducive to involving and integrating all social groups, including immigrants (principle 10). It encourages the development of universities themselves as institutions where there is a participatory style of management (principle 16). It invokes rules promoting partnership of different institutions - including HEIs - for the sake of implementing the principles of social responsibility and sustainable development (principle 17) as well as encouraging activities for the benefit of the natural environment and to counteract climate changes (principle 13) [35].

Polish universities implement Declaration's principles in various fields of their activity, i. e. in didactics, science, relations with stakeholders (the environment) and in managing the university. Some of the examined universities - the first signatories of the Declaration - undertake activity related to several principles of the Declaration (e.g. University of Silesia 
in Katowice, SGH Warsaw School of Economics, WSB University), others only a selected one (e.g. University of Bielsko-Biala, Warsaw Management University, Humanitas University in Sosnowiec). Some signatories (e.g. the Center of Postgraduate Medical Education, the Witelon State University of Applied Sciences in Legnica) do not report such activity at all (despite signing the Declaration).

As follows from the conducted analysis (Table 1), good practices of the examined HEIs most often refer to principle 2 of the Declaration, i.e. shaping social and civic attitudes as well as building a broadly understood community, communication, and social sensitivity.

The socially responsible activities undertaken by universities concern internal stakeholders, i.e. employees (e. g. codes of ethics, HRM strategies, civic budgets) and students (e.g. competitions, lectures, workshops, training in SR issues and effective implementation of its principles in organizations and events integrating foreign students with the Polish ones). They also address external stakeholders, mainly the local community, but also immigrants, foundations,, children in Africa. They are closely related to the popularization of science as well as climate policy and environmental protection. They also mean offering subjects and postgraduate studies familiarizing future graduates with the issues of social responsibility and sustainable development as well as the principles of their implementation in enterprises and other types of organizations.

It should be emphasized that students are also involved in promoting the SR idea and undertaking the related activities at universities, e. g. through thriving scientific circles (e.g. ENAKTUS).

Implementation of the university social responsibility principles in accordance with the Declaration of USR increases HEIs' openness to cooperation with the business community and develops their didactic offer in terms of shaping competences, pro-social and pro-environmental attitudes of future staff. The implementation of the Declaration additionally strengthens the organizational and management capabilities of the university through more effective management of resources, development of the academic staff and building the university's prestige as a generator of knowledge and a creator of new ideas (Społeczna odpowiedzialność, 2019).

The activities undertaken by the studied universities have brought and continue to bring a number of tangible benefits to their addressees (Table 1). They become a permanent part of the public space promoting the ideas of social responsibility. First of all, they shape students' awareness and commitment to the topical problems of the world, the local community, and the natural environment on the basis of universal values that are the foundation of social responsibility. They thus shape future elites of society, citizens of a globalized world aware of the existing opportunities and threats. They integrate the local community through activities popularizing knowledge and results of scientific research (children, youth, thirdage universities, science festivals, conferences), health programs (sports, culinary) targeted at the inhabitants. They shape civil society by developing volunteering among students, programs integrating immigrants with the local and the academic community, or directly addressed to groups in need of support. They promote their own region by popularizing science, but also by cooperation between a university and local authorities and enterprises with a view to its development. They make society and students aware of issues associated with social responsibility by introducing subjects on social responsibility and sustainable development to study programs, by offering postgraduate studies, organizing conferences and workshops on this subject. Through employees, students and doctoral students' participation in participatory budgets and offering them a chance to submit various proposals, HEIs involve them in managing the university. They build their involvement through implementing ethical codes or human resources management strategies.

According to the author, this activity would be much more effective if it were also associated with including socially responsible activities in the mission and development strategy of the university [19]. It is especially vital and justified because the SR activities support HEIs in building their competitive position in the environment and also contribute to deepening loyalty and involvement of the university's employees and students in the affairs of their Alma Mater.

The development of SR at HEIs can contribute to the further development of cooperation with the government administration in the process of creating the public policy for sustainable development and practices of university social responsibility, to strengthen cooperation of the academic community in Poland, to promote the SR idea in the broadly understood social awareness and to popularize this idea further. This activity is absolutely necessary and should be continued by Polish universities.

The growing importance and development of social responsibility at Polish universities is manifested by an increasing number of activities they have taken over the past years, as well as an increasing number of universities signing the SOU Declaration, thus by their responsible commitment to engage in popularizing its demands in their own activity. 


\section{References}

1. Spodarczyk E. The Concept of Corporate Social Responsibil-ity in the Micro and Small Enterprise Sector. In: Pinzaru F., Bratianu C. (ed.), Proceedings of the 12th European Conference on Manage-ment, Leadership and Governance. ACPI, 2016, pp. 248-254. (In Eng.).

2. Studzieniecki T. The development of cross-border cooperation in an EU microregion - a case study of the Baltic Sea Region, Procedia Economics and Finance, 2016, No. 39, pp. 235-241. (In Eng.).

3. Wolska G., Kizielewicz J. Corporate Social Responsibility in Poland - Theory and Practice. In: Raguž I. V., Krželj-Čolović Z. (ed.), Proceedings of Scientific Conference on Innovation, Leadership \& EntrepreneurshipChallenges of Modern Economy. University of Dubrovnik, 2015, pp. 143-154. (In Eng.).

4. Lina M. Gomez L. M., Vargas Preciado L. CSR Trends in the Top 100 Us Business Schools: A TheoryPractice Relationship. Education and Corporate Social Responsibility. International Perspectives Developments in Corporate Governance and Responsibility, 2013, vol. 4, pp. 155-183. (In Eng.).

5. Benedek A., Takács-György K. Employees Expectations Against the Workplace in Public Schools, International Journal of Contemporary Management, 2014, no. 13(1), pp. 66-83. (In Eng.).

6. Dima A. M., Vasilache S., Ghinea V., Agoston S. A Model of Academic Social Responsibility, Transylvanian Review of Administrative Sciences, 2013, no. 38 E, pp. 23-43. (In Eng.).

7. Barth M., Rieckmann M. Academic staff development as a catalyst for curriculum change towards education for sustainable development: an output perspective. Journal of Cleaner Production, 2012, vol. 26, no. 1, pp. 28-36. DOI: 10.1016/j.jclepro.2011.12.01. (In Eng.).

8. Cichowicz E., Nowak A. K. Społeczna odpowiedzialność wyższych uczelni w Polsce jako przejaw realizacji idei ekonomicznej teorii zrównoważonego rozwoju [Social Responsibility of Universities in Poland as a Manifestation of the Implementation of the Idea of the Economic Theory of Sustainable Development]. Gospodarka w Praktyce i Teorii, 2018, vol. 50 no. 1, pp. 7-19, available at: https://doi.org/10.18778/14293730.50.01 (accessed 30.10.19). (In Polish).

9. Kalinowska A., Batorczak A. Uczelnie wyższe wobec wyzwań celów zrównoważonego rozwoju [Universities and challenges facing the goals of sustainable development], Zeszyty Naukowe Politechniki Ślaskiej, Seria: ORGANIZACJA I ZARZĄDZANIE, 2017, no. 104, pp. 282-283. (In Polish).

10. Grobelna A., Marciszewska B. Undergraduate Students' Attitudes Towards Their Future Jobs in the Tourism Sector: Challenges Facing Educators and Business. In: Vasilenko D., Khazieva N. (eds.), Proceedings of the 4th International Conference on Management, Leadership and Governance, ACPI, 2016, pp. 138-145. (In Eng.).

11. Szelągowska-Rudzka K. Social Responsibility of Higher Education Institutions and Direct Participation of Academic Teachers. In: P. Ravesteijn P., de Waal B. M.E. (eds.). Proceedings of the 14th European Conference on Management, Leadership and Governance ACPI 2018, pp. 264-272. (In Eng.).
12. Rezolucja ONZ, 2015 [UN resolution], available at: http://odpowiedzialnybiznes.pl /wp-content/uploads/2017/10/ Agenda-na-rzecz-zrównoważonego rozwoju-2030.pdf (accessed 28.10.19). (In Polish).

13. World leaders adopt Sustainable Development Goals, available at: https://www.undp.org/content/undp/en/home/ presscenter/pressreleases/2015/09/24/undp-welcomes-adoption-of-sustainable-development-goals-by-world-leaders.ht$\mathrm{ml}$ (accessed 02.12.19). (In Eng.)

14. Our 2030 Vision, available at: https://www.unprme. org (accessed 02.12.19). (In Eng.).

15. Koksal Arac S., Madran C. Business School as an initiator of the transformation to sustainability: A content analysis for business school in PRME, Social Business 2014, vol. 4, no. 2, pp. 137-152. (In Eng.).

16. PRME (Principles for Responsible Management Education), available at: http://www.international.ue.wroc.pl/ partnerzy/19473/prme_princi-ples_for_responsible_management_education.html (accessed 28.10.19). (In Eng.).

17. Hiltzik M. Peter Drucker's Revolutionary Teachings Decades Old but Still Fresh, Los Angeles Times 2009, available at: https://www.latimes.com/archives/la-xpm-2009dec-31-la-fi-hiltzik31-2009dec31-story.html (accessed 02.12.19). (In Eng.).

18. ISO 26000 Guidance, available at: www.odpowiedzialnafirma.pl/o-csr/iso-26000 (accessed 12.05.2015). (In Polish).

19. Leja K. Zarządzanie uczelnią. Koncepcje i współczesne wyzwania, Wyd. II uzupełnione [University management. Concepts and contemporary challenges, ed. II completed], Wolters Kluwer business, Warszawa, 2013. (In Polish).

20. Szelągowska-Rudzka K., Spodarczyk E. Społecznie odpowiedzialny student w społecznie odpowiedzialnej uczelni-w świetle wyników badania [Socially Responsible Student in Socially Responsible University - a Study Results], Research Papers of Wroclaw University of Economics, 2018, no. 516, pp. 87-98. (In Polish).

21. Geryk M. Społeczna odpowiedzialność uczelni [University Social Responsibility], Oficyna Wydawnicza Szkoła Gówna Handlowa, Warszawa, 2012. (In Polish).

22. Gómez L. M., Alvarado Y. \& Pujols A. Implementing University Social Responsibility in the Caribbean: Perspectives of Internal Stakeholders. Revista Digital de Investigación en Docencia Universitaria, 2018, vol. 12, no. 1, pp. 101-120. doi: http://dx.doi.org/ 10.19083/ ridu.12.714. (In Eng.).

23. Popowska M. CSR education in Poland-current situation and future challenges. Horyzonty Wychowania, 2016, vol. 15, no. 33, pp. 87-101, doi: 10.17399/ HW.2016.153306. (In Eng.).

24. Społeczna odpowiedzialność. Znaczenie dla uczelni i sposoby wdrażania [Social Responsibility. Importance for universities and implementation methods] MNiSW, Warszawa, 2019, available at: SOU_publikacja.pdf (accessed 30.10.19). (In Polish).

25. Zespół ds. Zrównoważonego Rozwoju i Społecznej Odpowiedzialności Przedsiębiorstw [Team for Sustainable Development and Corporate Social Responsibility], available at: https://www.gov.pl/web/ inwestycje-rozwoj/o-zespole (accessed 30.10.19). (In Polish). 
26. Deklaracja Społecznej Odpowiedzialności Uczelni, 2017 [Declaration of University Social Responsibility], available at: https://www.ujk. edu.pl/webujk/resources/BPiI/konferencje/deklaracja\%20spolecznej\%20odpowiedzialnosci\%20 uczelni.pdf (accessed 30.10.19). (In Polish).

27. Lista sygnatariuszy Deklaracji Społecznej Odpowiedzialności Uczelni [List of Signatories to the Declaration], available at: https://www. gov.pl/web/inwestycje-rozwoj/ wydarzenia-csr (accessed 30.10.19). (In Polish).

28. HR Excellence in Research Award, available at: https://euraxess.ec. europa.eu/jobs/hrs4r (accessed 05.12.19). (In Eng.).

29. Budżet obywatelski [Citizens' Budget], available at: https://pg.edu.pl/ budzet_obywatelski/strona-glowna (accessed 30.10.19). (In Polish).

30. Most wiedzy [Knowledge Bridge], available at: https:// mostwiedzy. pl/pl (accessed 30.10.19). (In Polish).
31. Klimatyczny i Środowiskowy Stan WyjątkowyUchwała WNB [Climate and Environmental Emergency WNB resolution], available at: https://uni.wroc.pl/klimatyczny-i-srodowiskowy-stan-wyjatkowy-uchwala-wnb/ (accessed 30.10.19). (In Polish).

32. Wybierz studia [Choose your Studies], available at: https://www. humanitas.edu.pl (accessed 30.10.19). (In Polish).

33. Popularyzacja nauki [Popularization of the Science], available at: https://uni.wroc.pl/popularyzacja-nauki (accessed 30.10.19). (In Polish).

34. Strategia ZZL (Nauczyciele Akademiccy ALK [Human Resource Management Strategy (Academic Staff at KU)], available at: https:// www.kozminski.edu.pl/pl/kadra-i-badania/etyka-w-nauce/ (accessed 30.10.19). (In Polish).

35. Sustainable Development Goals, 2015, available at: https://www.undp.org/content/undp/en/home/sustainable-development-goals.html (accessed 06.12.19). (In Eng.).

Submitted on 29.09.2019

Accepted on 24.10.2019

\section{Information about the author:}

Katarzyna I. Szelągowska-Rudzka - Dr. hab. (Economics in the field of Management), Research and Teaching Staff at Department of Management and Economics, Gdynia Maritime University; k. szelagowska-rudzka@wpit.umg.edu.pl.

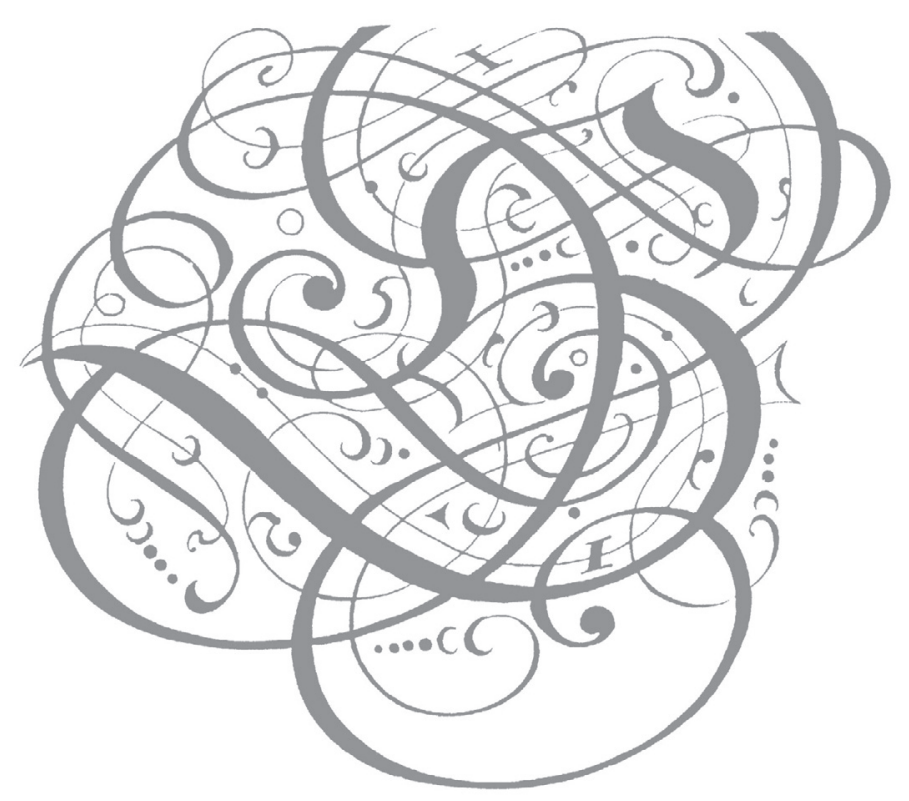

